Citation: Lara-Ruiz, G. F., PachecoContreras, V. I., López-Aranda, E., Romero-Cruz, A., \& Gabilán-Linares, E. (2021) Effect of indole-3-acetic acid on vegetative propagation by cutting cuatomate (Solanum glaucescens Zucc.). Agro Productividad. https://doi. org/10.32854/agrop.v14i12.2097

Editor in Chief: Dr. Jorge Cadena Iñiguez

Received: July 21, 2021.

Accepted: November 29, 2021.

Published on-line: December 30, 2021

Agro Productividad, 14(12). December. 2021. pp: 127-134.

This work is licensed under a Creative Commons Attribution-NonCommercial 4.0 International license.

\section{Effect of indole-3-acetic acid on vegetative propagation by cutting cuatomate (Solanum glaucescens Zucc.)}

\author{
Lara-Ruiz, Gabriela F. ${ }^{1}$; Pacheco-Contreras, Víctor I. $^{{ }^{*}}{ }^{\text {; }}$ López-Aranda, Erika $^{1}$; \\ Romero-Gruz, Anabel ${ }^{1}$; Gabilán-Linares, Eleodoro ${ }^{1}$ \\ 1 Instituto Tecnológico Superior de Acatlán de Osorio, Puebla; Acatlán de Osorio, Puebla, Mexico. C. P. \\ 74949 \\ * Correspondence: victor.pacheco@itsao.edu.mx
}

\begin{abstract}
Objective: To evaluate the effect of indole-3-acetic acid and budwood type in the vegetative propagation by cutting cuatomate (Solanum glaucescens Zucc.) and to describe the phenological stages, in order to increase production.

Design/Methodology/Approach: A completely randomized design with a 22 factorial design was used to estimate the effect of two concentrations of indole-3-acetic acid (1000 and $10000 \mathrm{ppm})$ and budwood type (secondary and tertiary) on the number of leaves and sprouts of the plant. With regard to propagation, 30-cm budwoods from secondary and tertiary branches of cuatomate were used; transversal and diagonal cuts were made at the ends of the branches that generate the canopy and the root, respectively. Data was subject to an analysis of variance, using the general linear model procedure.

Results: Highly significant differences $(\mathrm{p} \leq 0.01)$ were observed between the variables under study. Higher number of leaves and sprouts ( 16.700 and 20.000, respectively) were observed in tertiary budwoods inoculated with $1000 \mathrm{ppm}$ of IAA. In the evaluation of the phenological stages, the first bud appeared at 30 days, while the first leaf and flowers appeared 40 and 180 days after inoculation, respectively.

Study limitations/implications: Commercial candelilla wax was applied in the transversal cut to prevent attacks by pathogens and every single budwood was completely covered with indole-3-acetic acid.

Findings/conclusions: The use of indole-3-acetic acid in the vegetative propagation of cuatomate would be an alternative to increase its production; promoting a sustainable activity in the Mixtec region of Puebla.
\end{abstract}

Keywords: Auxin, wild plant, Mixtec

\section{INTRODUCTION}

Mexico has an abundance of genetic resources; its genetic information has actual or potential value and utility which forms the basis of humanity, fulfills basic needs, and contributes to counteract hunger and poverty (Estrella et al., 2005; Martínez-Pérez et al., 2012). The Low Mixtec region of Puebla is located in the south of the State of Puebla, Mexico; it is characterized by its warm dry or semi-dry climate. Its poor soils and rugged orography make it one of the most marginalized areas of the country (Guízar-Nolazco et al., 2010; Hernández et al., 2011). The 
inhabitants of the region consume a great variety of wild plants. Cuatomate (Solanum glaucescens Zucc.) is a wild plant on the process of domestication; it has a high economic, ecological, and nutritional potential and is primarily used for human consumption in the Low Mixtec region of Puebla, Mexico (Gutiérrez-Rangel et al., 2011; Medina-Galicia et al., 1996). Mixtec farmers identify three types of cuatomate, depending on the external color of the fruit (from its early stages of development to the beginning of its ripening): green, white or ashy, and mottled (Gutiérrez-Rangel et al., 2011). Cuatomate, as a phytogenetic resource, is closely related to the traditional lore (farmers' lore); therefore, it is widely used, has great value and specific functions (Martínez-Pérez et al., 2012). Its fruit is used to prepare sauces and stews, replacing tomatoes and tiny green tomatillos; according to the inhabitants of the region, this fruit has an exquisite and irreplaceable taste (Hernández-Rojas et al., 2018). The transportation, marketing, and promotion of cuatomate in the United States by Mixtec emigrants has led to an increasingly unsatisfied demand (Gutiérrez-Rangel et al., 2011; Hernández-Rojas et al., 2018). This situation has contributed to the acceleration of domestication. However, this practice indirectly promotes the deterioration and disappearance of cuatomate in its natural habitats, since this crop method involves taking plants away from their natural environment. Therefore, alternatives aimed at the use of the species in a sustainable agriculture framework are required. There are few studies about cuatomate; however, the experience of Mixtec farmers indicates that propagation is the main problem in cuatomate production. Although sexual propagation is commonly successful and relatively simple, 50 to $60 \%$ of germinated plants are male (Medina-Galicia et al., 2011), as a result of the heterostyly phenomenon. Some plants produce fertile and long-styled flowers, while others have short-styled flowers that cannot be fertilized. Another method of propagation is by bud; however, this method is expensive, since a specialized laboratory is required. Therefore, vegetative propagation is an alternative to produce fertile plants: uniform plants with similar characteristics to the mother plant are obtained using this method (Hartmann et al., 2014). Vegetative propagation consists of separating a part of the mother plant (usually budwoods); this part is then placed under certain conditions and is induced to form roots and shoots, thus obtaining a new plant (Contreras G. and Almeida Puentes, 2006; Hartmann et al., 2014). The application of auxins to species that face difficulties rooting increases the possibility of obtaining plants by vegetative propagation and, in some species, it is essential for roots to form (Hartmann et al., 2014). Auxins are hormones that regulate plant growth; among other effects, they influence growth, cell division, and root formation. Therefore, they are frequently and increasingly applied in agriculture (Burgos et al., 2009; Garay-Arroyo et al., 2014). The most important natural auxin is indole-3-acetic acid (IAA) (Martínez et al., 2016). Therefore, the objective of this study was to establish the best concentration of indole-3-acetic acid and origin of cuatomate (Solanum glacescens Zucc.) budwoods for its vegetative propagation by cutting, as well as to describe the phenological stages - taking as parameters the time of budwood sprouts, and the time when the first bud, leaf, flower, and fruit appear-, in order to obtain fertile plants and contribute to their domestication process in the Low Mixtec region of Puebla. 


\section{MATERIALS AND METHODS}

\section{Location of the Experiment}

The study was performed in a nursery covered with shade mesh, at the experimental field of the Instituto Superior de Acatlán de Osorio, in the municipality of Acatlán de Osorio $\left(18^{\circ} 11.9^{\prime} \mathrm{N}\right.$ and $98^{\circ} 3^{\prime} \mathrm{W}$, at an altitude of $1180 \mathrm{~m}$ ), Puebla, Mexico. The municipality of Acatlán de Osorio has an area of $483.48 \mathrm{~km}^{2}$. Its climate transitions from dry -in the Lower Mixtec region of Puebla - to the warm - in the Valley region. Semi-warm subhumid climate with rains in summer has been identified, in the mountainous areas of the North and small areas in the Southeast-Southwest. The area between the mountainous areas and the lower parts of the municipality has a warm sub-humid climate with rains in summer. The latter area also has a very hot semi-dry climate.

\section{Experimental Design}

A completely randomized design with a $2^{2}$ factorial design was used to estimate the effect of two concentrations of indole-3-acetic acid (1000 and $10000 \mathrm{ppm}$ ) and budwood type (secondary and tertiary) on the number of leaves and sprouts of the plant. The experimental and sampling unit was made up of one budwood. Twenty repetitions were carried out, obtaining a total of 80 experimental units.

\section{Vegetative propagation by cutting of cuatomate}

To propagate the cuatomate, budwoods taken from secondary and tertiary branches were used. The said branches were collected in September 2013, in the community of La Huerta, located in the municipality of Acatlán de Osorio. Forty 30-cm long budwoods from each type of branch (secondary and tertiary) were cut. A cross cut was made at one end of each budwood (the part that will give rise to the canopy), while a diagonal (wedgeshaped) cut was made at the other end (the part from which the root will grow). In the transversal cut, commercial candelilla wax was applied to prevent attacks by pathogens; the diagonal cut was moistened and subsequently fully immersed in the IAA hormone, using the concentrations mentioned in this study.

\section{Phenology}

For the description of the phenological stages, the first shoot of the first bud of 80 plants was registered, as well as the first leaf and flower. The number of leaves and sprouts were considered as response variables.

\section{Fruit Evaluation}

Fruit development was evaluated recording the diameter of the fruits of the biggest and the smallest plants, using a Mitutoyo 530-104 digital vernier caliper (standard and millimeter), with a range of $0-150 \mathrm{~mm}$.

\section{Statistical Analysis}

Using the general linear models (GLM) procedure, an analysis of variance was carried out to determine the effect of IAA concentrations and budwood type on the number of 
leaves and the sprouts of the cuatomate plant. For each of the effects, the comparison of means was performed using the least significant difference method. The SAS (Statistical Analysis System, version 9.0) statistical package was used to perform all the analyses. An alpha value $\leq 0.05$ was considered to be a significant effect. The following model was used to determine the effect of the treatments on the response variables (number of leaves and sprouts):

$$
Y_{i j}=\mu+I_{j}+V_{k}+\varepsilon_{i j}
$$

Where: $Y_{i j}=$ Response of the observations obtained, expressed as number of leaves and sprouts in the $\mathrm{i}$-th plant, as a result of the $j$-th concentration of indole- 3 -acetic acid and $k$-th budwood type. $V_{k}=$ treatment. $\mu=$ World mean population. $I_{j}=$ Effect of the $j$-th treatment. $\varepsilon_{i j}=$ Experimental error of the observations obtained, expressed as number of leaves and sprouts in the $i$-th plant, as a result of $j$-th treatment.

\section{RESULTS AND DISGUSSION}

\section{Estimation of the effect of the IAA concentration over the number of leaves and plant sprouts}

The results of the statistical analysis showed that the IAA concentration, the budwood type, and their interaction significantly affect $(\mathrm{p} \leq 0.01)$ the number of leaves and sprouts of the cuatomate. IAA concentrations had highly significant differences ( $\mathrm{s} \leq 0.01)$ : 1000-ppm IAA budwoods had significantly more leaves and sprouts than 10000-ppm IAA budwoods (Figure 1).

Secondary and tertiary branches had highly significant differences $(p \leq 0.01)$ with regard to the number of leaves and sprouts: tertiary branches had a higher number of leaves and sprouts than secondary branches (Figure 2).

The analysis of the interaction of the IAA concentration with the budwood type showed a significant difference $(\mathrm{p} \leq 0.05)$ in the number of leaves and sprouts; the TER1000

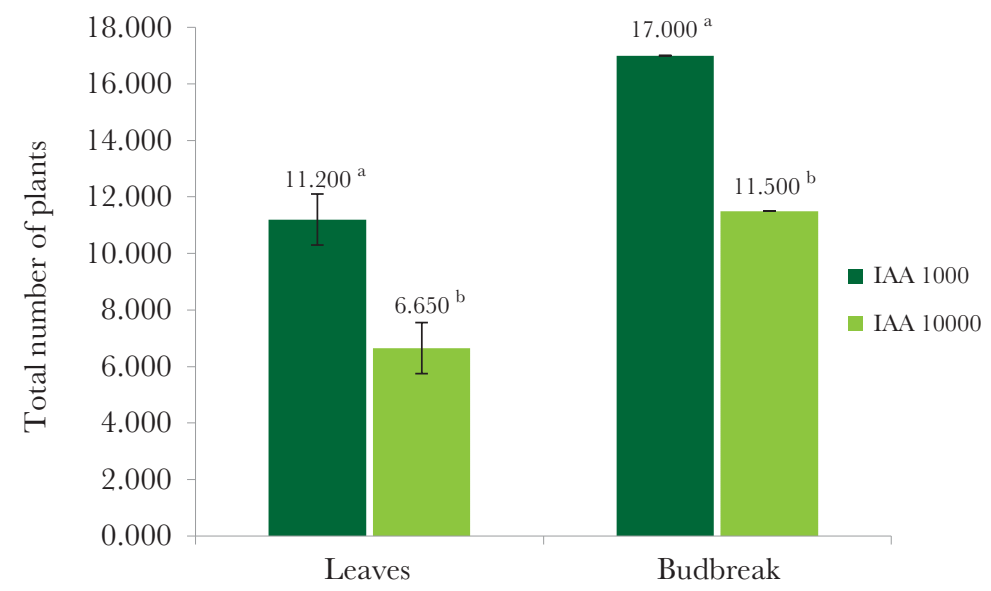

Figure 1. Number of leaves and budbreak due to IAA concentration. Means with different letters are statistically different $(\mathrm{p}<0.01)$. 


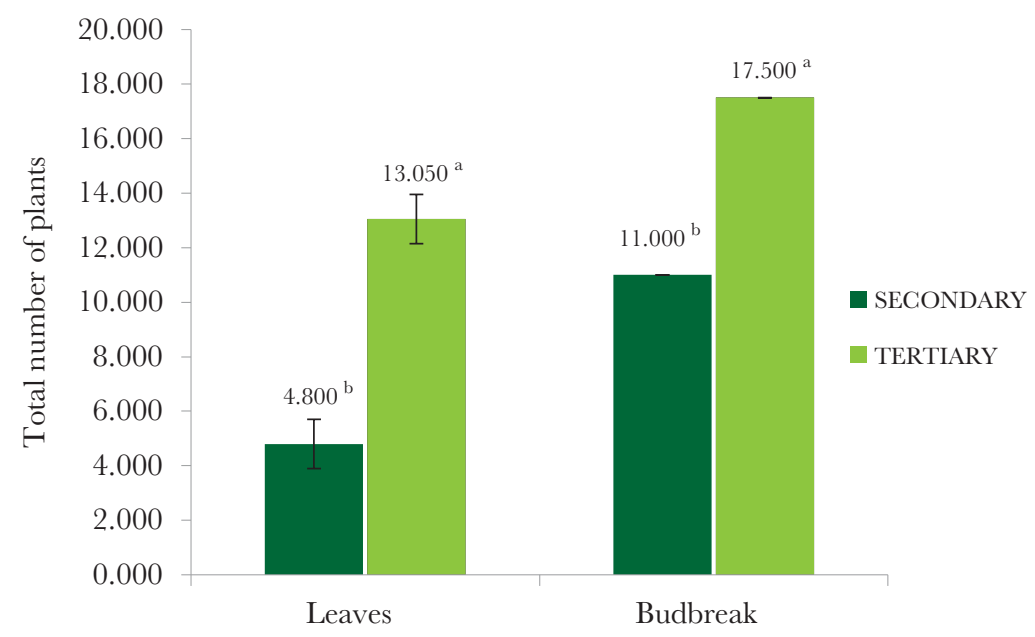

Figure 2. Number of leaves and budbreak due to secondary and tertiary rods. Means with different letters are statistically different $(\mathrm{p}<0.01)$.

(tertiary branch $+1000 \mathrm{ppm}$ of IAA) treatment showed more leaves and sprouts than other treatments (Figure 3).

Studies about the cuatomate plant have mainly been focused on its importance as an endemic plant that grows wild in the Mixtec region, where it is framed as an important food source in rural areas (Gutiérrez-Rangel et al., 2011; Martínez-Pérez et al., 2012). According to Gutiérrez-Rangel et al., (2011), Martínez (2004) studied the cuatomate adaptation to an intensive production system and determined that the use of $50 \%$ half shade is suitable for the development of this species; however, Martinez (2004) also established that the application of different nitrogen, phosphorus, and potassium concentrations had no significant effect on the cuatomate production. There are not many studies about the vegetative propagation

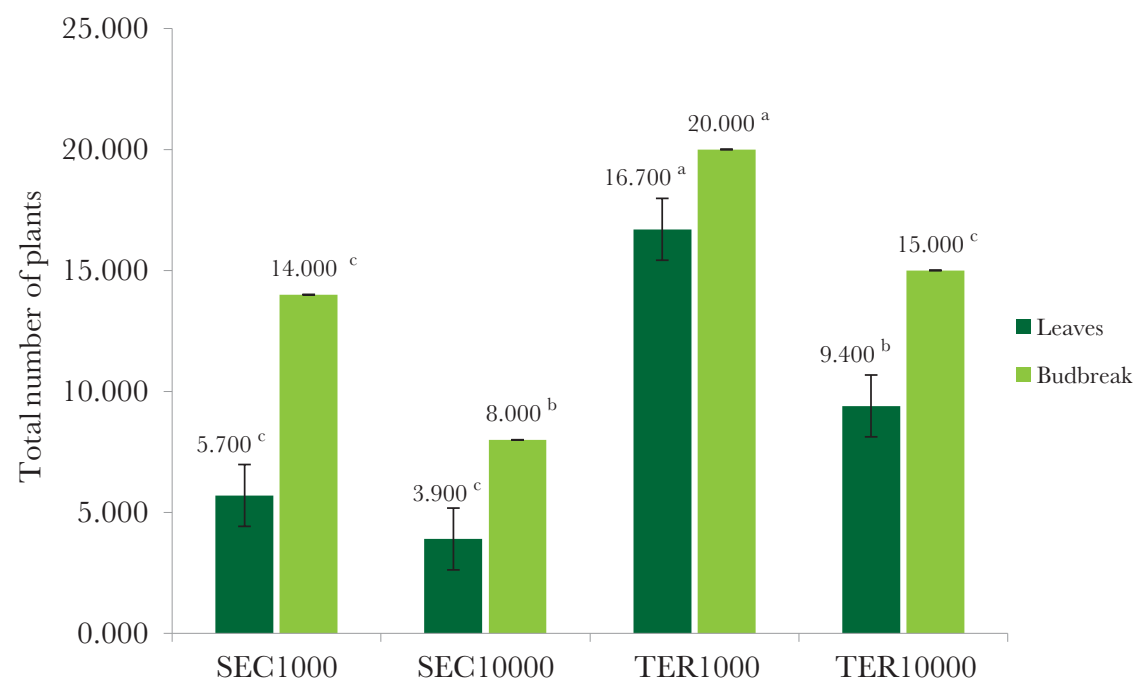

Figure 3. Number of leaves and budbreak due to the treatments. Means with different letters are statistically different (p<0.01). SEC1000: Secondary to 1000 ppm; SEC: Secondary to 10000 ppm; TER1000: Tertiary to 1000 ppm; TER: Tertiary to 10000 ppm. 
of this species, although the use of auxins increases the possibility of obtaining plants by vegetative propagation in species that have difficulties establishing roots (Hartmann et al., 2014). IAA is the most important natural auxin and its application in some crops, such as zucchini (Cucurbita pepo L.), is related to the sprouts and growth of the fruit ( $\mathrm{Li}$ et al., 2005). The same behavior was found in melon crops: significant differences in number of fruits/ plants was observed, when 50-, 100-, 150-, and 200-mg L ${ }^{-1}$ doses of IAA were applied (Montaño-Mata and Méndez-Natera, 2009).

\section{Phenological Evaluation}

Phenological stages refer to the periodic rhythm or biological stages of a plant such as flowering, shoots, and ripening of the fruit. These phenomena are related to the local climate (Pérez-Hernández et al., 2018; Solórzano-Vega, 2007). The first bud was observed 30 days after IAA inoculation, while the first leaf and flower appeared 40 and 180 days after inoculation, respectively (Table 1 and Figure 4).

\section{Fruit Evaluation}

First bud, leaf, and flower are indicators of fruit generation. The fruit has a gradual development; industrialization requires ripe fruits (Figure 5). The average growth was $0.02 \mathrm{~mm}$ in diameter per day in a period of 23 days (Table 2); in average, the plant started to bear fruits 8 months after the sprouts; the first harvest was obtained after a year. The average diameter at the ripening stage was $3.8 \mathrm{~cm}$. The average weights obtained during the experiment were $30-38 \mathrm{~g}$.

According to Medina (2011), the main physical and physiological aspects of the cuatomate crop — such as its reproduction, handling, and conservation - are not well known; however, in other studies, Medina also shows that its commercial significance lies in the following aspects: cuatomate is only consumed by $51 \%$ of producers; $41 \%$ both consume it and sell it; while the remaining $8 \%$ considered it as a hugely relevant part of their culture, as a traditional element of the family diet over generations.

\section{CONGLUSIONS}

The highest number of leaves (11.2) and sprouts (17) were obtained from tertiary budwoods inoculated with 1000 ppm of IAA. The first bud was observed 30 days after IAA inoculation, while the first leaf and flower appeared 40 and 180 days after inoculation, respectively. The plant began to bear fruits after an average of 8 months; the first harvest

Table 1. Phenological stages of the cuatomate during the experiment.

\begin{tabular}{l|c|c}
\multicolumn{1}{c|}{ Activity } & Date & Days \\
\hline Budwood collection & $09 / 26 / 2013$ & 01 \\
\hline Hormone application and bag placement & $09 / 26 / 2013$ & 01 \\
\hline First bud & $10 / 26 / 2013$ & 30 \\
\hline First leaf & $11 / 05 / 2013$ & 40 \\
\hline First flower & $03 / 27 / 2014$ & 180 \\
\hline
\end{tabular}



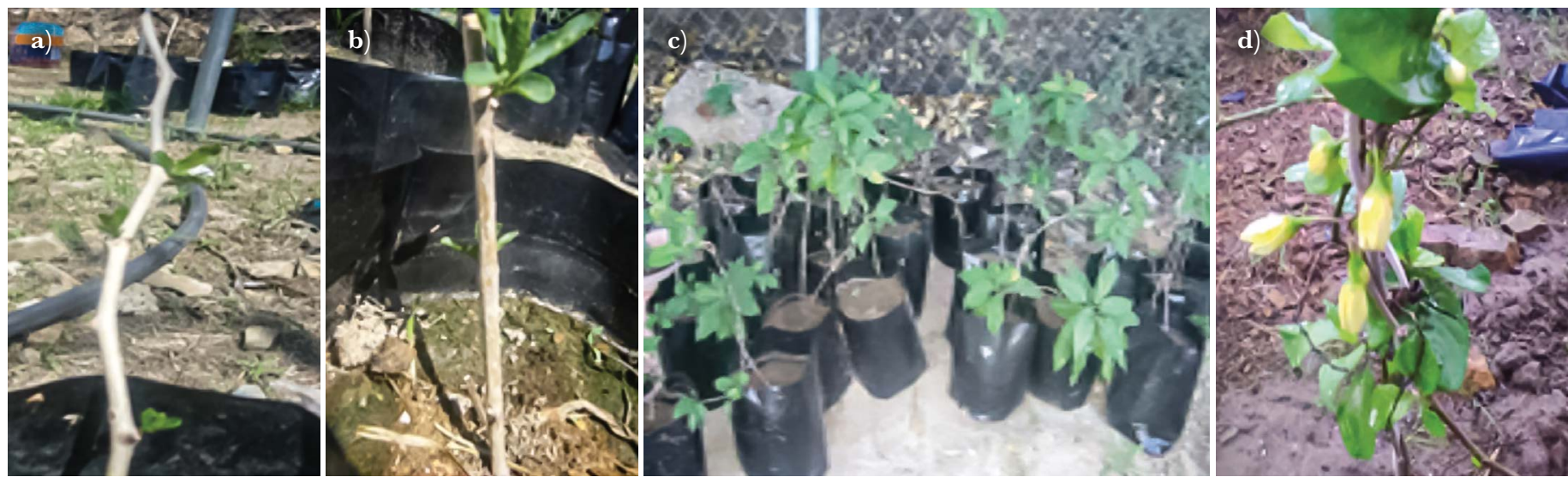

Figure 4. Phenological stages of cuatomate during the experiment: a) Shoot of the first leaf, b) Formation of leaves, c) Formation of leaves and small branches, d) Flowering of the cuatomate.
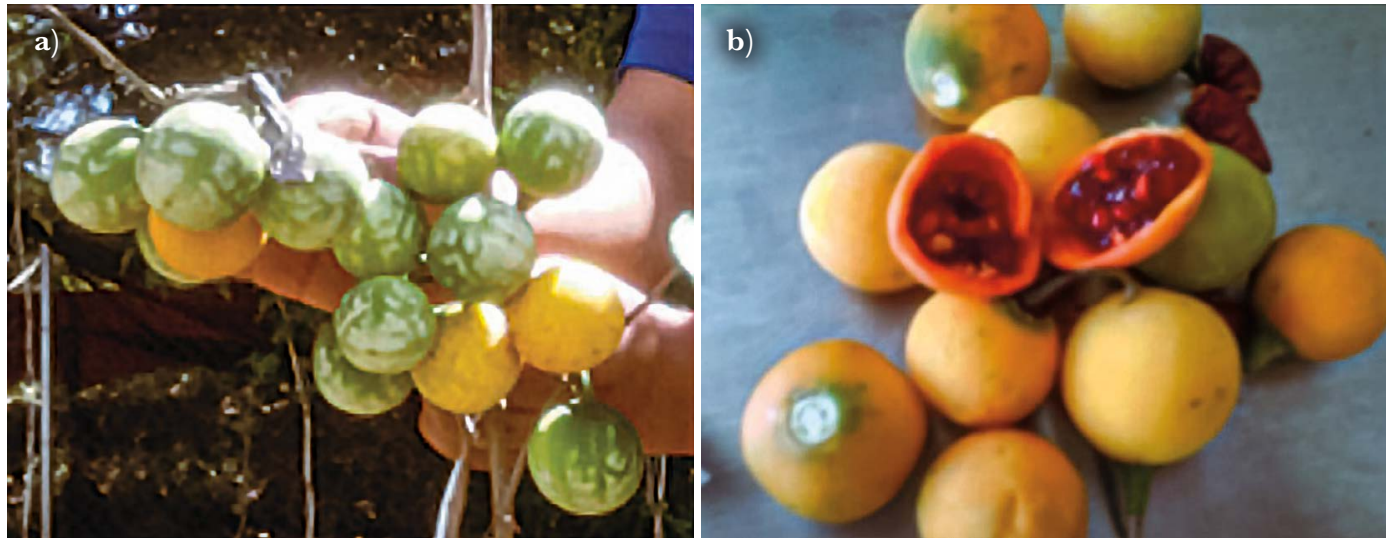

Figure 5. Cuatomate in its different ripening stages: a) Cluster of physiologically mature cuatomate, b) Ripe cuatomate ready to prepare salsa roja.

Table 2. Development of the cuatomate fruit during the experiment.

\begin{tabular}{c|c|c|c|c|c|c|c}
\hline Date & $\mathbf{0 6 / 2 5 / 2 0 1 4}$ & $\mathbf{0 6 / 2 6 / 2 0 1 4}$ & $\mathbf{0 6 / 3 0 / 2 0 1 4}$ & $\mathbf{0 7 / 0 4 / 2 0 1 4}$ & $\mathbf{0 7 / 0 8 / 2 0 1 4}$ & $\mathbf{0 7 / 1 4 / 2 0 1 4}$ & $\mathbf{0 7 / 1 8 / 2 0 1 4}$ \\
\hline Plant 1 & $0.5 \mathrm{~cm}$ & $0.52 \mathrm{~cm}$ & $0.55 \mathrm{~cm}$ & $0.55 \mathrm{~cm}$ & $0.64 \mathrm{~cm}$ & $0.7 \mathrm{~cm}$ & $0.9 \mathrm{~cm}$ \\
\hline Plant 2 & $3.37 \mathrm{~cm}$ & $3.4 \mathrm{~cm}$ & $3.56 \mathrm{~cm}$ & $3.59 \mathrm{~cm}$ & $3.60 \mathrm{~cm}$ & $3.61 \mathrm{~cm}$ & $3.63 \mathrm{~cm}$ \\
\hline
\end{tabular}

was obtained after one year. The use of IAA in the vegetative propagation of the cuatomate would be an alternative to increase its production, as a result of its widespread acceptance in the regional gastronomic industry and its commercialization in the United States by Mixtec emigrants. It would also be a sustainable activity for the Mixtec region of Puebla.

\section{ACKNOWLEDGEMENTS}

The authors would like to thank Mr. Francisco Hernández Rosas, Research Professor at the Colegio de Postgraduados - Campus Córdoba, and Mr. Gaspar Manuel Parra Bracamonte, Research Professor at Centro de Biotecnología Genómica of the Instituto Politécnico Nacional, who reviewed this manuscript. 


\section{REFERENGES}

Burgos, A. M., Cenóz, P. J., \& Prause, J. (2009). Efecto de la aplicación de auxinas sobre el proceso de enraizamiento de estacas de dos cultivares de mandioca (Manihot esculenta Crantz). Revista Cientifica UDO Agricola, 9(3), 539-546.

Contreras G., I., \& Almeida Puentes, J. (2006). Micropropagación del tomate de árbol (Cyphomandra betacea (Cav.) Sendtn.), Solanaceae silvestre usada en la alimentación humana. 47(2), 9-13.

Estrella, J., Manosalvas, R., Mariaca, J., \& Ribadeneira, M. (2005). Biodiversidad y recursos genéticos: Una guia para su uso y acceso en el Ecuador. http://www.ecociencia.org/archivos/Biodiversidadyrecursosgeneti cos-110922.pdf

Garay-Arroyo, A., de la Paz Sánchez, M., García-Ponce, B., Álvarez-Buylla, E., \& Gutiérrez, C. (2014). La Homeostasis de las Auxinas y su Importancia en el Desarrollo de Arabidopsis Thaliana. REB. Revista de Educación Bioquímica, 33(1), 13-22.

Guízar-Nolazco, E., Granados-Sánchez, D., \& Castañeda-Mendoza, A. (2010). Flora Y Vegetación En La Porción Sur De La Mixteca Poblana. Revista Chapingo Serie Ciencias Forestales Y Del Ambiente, XVI(2), 95-118. https://doi.org/10.5154/r.rchscfa.2010.04.019

Gutiérrez-Rangel, N., Medina-galicia, A., Ocampo-fletes, I., Antonio-López, P., \& Pedraza-santos, M. E. (2011). CONOCIMIENTO TRADICIONAL DEL “CUATOMATE” (Solanum glaucescens Zucc) EN LA MIXTECA BAJA OF PUEBLAA, MÉXICO. AGRICULTURA, SOCIEDAD Y DESARROLLO, $8(3), 204-420$.

Hartmann, H. T., Kester, D. E., Davies, F. T., \& Geneve, R. L. (2014). Hartmann and Kester ' S Plant Propagation. Hartmann \& Kester's Plant Propagation: Principles and Practices, 928.

Hernández-Rojas, G. J., Sandoval-Castro, E., Gutiérrez-Rangel, N., Pineda-Pineda, J., Sánchez-Vélez, A., \& Espinoza-Hernández, V. (2018). Concentración de nutrimentos en la solución nutritiva y rendimiento de "cuatomate" (Solanum glaucescens Zucc.). Revista Mexicana de Ciencias Agrícolas, 9(1), 123-136. https:// doi.org/10.29312/remexca.v9i1.853

Hernández, J. E., Franco, J. A., Villarreal, O. A., Camacho, J. C., \& Pedraza, R. M. (2011). CARACTERIZACIÓN SOCIOECONÓMICA Y PRODUCTIVA DE UNIDADES CAPRINAS FAMILIARES EN LA MIXTECA POBLANA. Arch. Zootec., 60(230), 175-182.

Li, X.-X., Yasukawa, J., \& Hayata, Y. (2005). Role of endogenous Indole -3- acetic acid in fruit Set of Zucchini. J.Japan. Sco. Hort. Sci., 74(2), 167-169.

Martínez-Pérez, A., Antonio López, P., Gil-Muñoz, A., Cuevas-Sánchez, J., \& Axayácatl. (2012). PLANTAS SILVESTRES ÚTILES Y PRIORITARIAS IDENTIFICADAS EN LA MIXTECA POBLANA, MÉXICO. Acta Botanica Mexicana, 98, 73-98.

Martínez, G., Ácido, B. D. E., Vega-celedón, P., Martínez, H. G., \& González, M. (2016). BIOSÍNTESIS DE ÁCIDO INDOL-3-ACÉTICO Y PROMOCIÓN Review promoting by bacteria. https://doi.org/10.13140/ RG.2.1.5158.3609

Medina-galicia, A., Ocampo-fletes, I., Pedraza-santos, M. E., Postgraduados, C. De, \& Cholula, S. P. (1996). CONOCIMIENTO TRADICIONAL DEL “CUATOMATE” (Solanum glaucescens Zucc) EN LA MIXTECA BAJA OF PUEBLAA, MÉXICO. 1977.

Medina-galicia, A., Ocampo-fletes, I., Pedraza-santos, M. E., Postgraduados, C. De, \& Cholula, S. P. (2011). CONOCIMIENTO TRADICIONAL DEL “CUATOMATE” (Solanum glaucescens Zucc) EN LA MIXTECA BAJA OF PUEBLA, MÉXICO. Agricultura, Sociedad y Desarrollo, 8(3), 406-420.

Montaño Mata, N. J., \& Méndez Natera, J. R. (2009). Efecto del ácido indol acético y ácido naftaleno acético sobre el rendimiento en melón (Cucumis melo L.). Revista Cientifica UDO Agricola, 9(4), 793-801.

Pérez Hernández, A., Quero Carrillo, A. R., Escalante Estrada, J. A. S., Rodríguez González, M. T., Garduño Velázquez, S., \& Miranda Jiménez, L. (2018). Fenología, biomasa y análisis de crecimiento de cultivares de sorgo forrajero en valles altos. Agronomía Costarricense, 42(2), 107-117. https://doi.org/10.15517/rac. v42i2.33782

Solórzano Vega, E. (2007). Guías fenológicas para cultivos básicos. 